\title{
Workshop Pembuatan Multimedia Pembelajaran Menggunakan Microsoft Power Point Untuk Guru Sekolah Dasar
}

\author{
Tri Wardati Khusniyah, Riko Ariyanto, Reny Oktiana Dewi Erwanda \\ STKIP Modern Ngawi \\ neeaccel@gmail.com
}

Telah dilaksanakan kegiatan Pengabdian kepada Masyarakat (PkM) dalam bentuk Workshop Pembuatan Multimedia Pembelajaran Menggunakan Microsoft Power Point. Kegiatan ini bertujuan untuk melatih peserta merancang dan membuat multimedia pembelajaran menggunakan Microsoft Power Point dengan mempraktikkan secara langsung dibantu instruktur. Pengalaman mempraktikkan pembuatan multimedia pembelajaran secara langsung membuat guru menjadi lebih terampil merancang dan membuat multimedia pembelajaran pembelajaran yang menarik guna menunjang efektivitas dan efisiensi pembelajaran di kelas sehingga keberhasilan tujuan pembelajaran dapat dicapai. Metode yang digunakan berupa pemaparan materi, diskusi, dan praktik. Praktik dilaksanakan dalam tiga tahap, yaitu persiapan desain multimedia, persiapan bahan materi, dan pembuatan komponen multimedia pembelajaran. Kegiatan ini berlangsung secara daring (dalam jaringan) melalui aplikasi Google Meet mengingat adanya pandemi Covid-19. Sasaran kegiatan ini adalah mahasiswa, guru, dan masyarakat umum, khususnya di Kabupaten Ngawi. Hasil kegiatan ini menunjukkan bahwa peserta mampu membuat multimedia pembelajaran menggunakan Microsoft Power Point dengan baik. Peserta antusias mengikuti keseluruhan acara. Kegiatan workshop berjalan dengan sangat baik.

Kata kunci : Media, pembelajaran, multimedia, Microsoft Power Point

\begin{abstract}
Community Service (PkM) activities have been carried out in the form of a Workshop on Making Learning Multimedia Using Microsoft Power Point. This activity aims to train participants to design and create learning multimedia using Microsoft Power Point by practicing directly with the help of the instructor. The experience of practicing making learning multimedia directly makes teachers more skilled in designing and making interesting learning multimedia in order to support the effectiveness and efficiency of learning in the classroom so that the success of learning objectives can be achieved. The method used is in the form of material presentation, discussion, and practice. The practice is carried out in three stages, namely preparation of multimedia design, preparation of material materials, and manufacture of learning multimedia components. This activity takes place online (on a network) through the Google Meet application in view of the Covid-19 pandemic. The targets of this activity are students, teachers, and the general public, especially in Ngawi Regency. The results of this activity showed that the participants were able to make learning multimedia using Microsoft Power Point well. Participants enthusiastically participated in the whole event. The workshop activities went very well.
\end{abstract}

Keywords: Media, learning, multimedia, Microsoft Power Point 


\section{PENDAHULUAN}

Pendidikan adalah salah satu bidang yang terus berkembang untuk meningkatkan kualitas pendidikan terutama dalam beradaptasi dengan era yang mendorong reformasi sistem pendidikan. Salah satu sumber utama peningkatan kualitas pendidikan adalah kualitas pembelajaran di kelas. Banyak factor yang dianggap sebagai penentu utama kualitas pendidikan, salah satunya guru (Kirom, 2017). Selain itu, guru juga dianggap sebagai pengendali pembelajaran, berperan dalam memutuskan arah untuk mencapai tujuan pembelajaran dan mengelola siswa.

Pembelajaran di kelas terus berkembang, dan peran guru dan siswa perlu diubah (Tri Wardati Khusniyah et al., 2021). Berawal dari filosofi pembelajaran tradisional, guru hanya berperan sebagai pembawa pesan (transformer) komunikasi aktif, sedangkan siswa berperan pasif, berkembang ke arah konsep pembelajaran modern, dan meyakini bahwa pembelajaran aktif sinergi antara guru dan siswa itu penting. Menurut Sudrajat (2008), salah satu peran guru yang dimaksud adalah sebagai perancang pembelajaran, diharapkan mampu merancang pembelajaran yang baik dan mencakup desain media pembelajaran.

Sebagai alat yang digunakan dalam proses pembelajaran, media pembelajaran digunakan untuk menyampaikan informasi pembelajaran dari guru kepada siswa, tentunya sangat membantu efektivitas dan efisiensi proses pembelajaran. Semakin baik media pembelajaran yang digunakan maka semakin berhasil pencapaian tujuan pembelajaran. Bretz (dalam Musfiqqon 2012: 70) membagi media menjadi tiga jenis, yaitu media visual, media audio, dan media kinestetik.

Kemajuan teknologi pada Pendidikan saat ini sangat beragam. Salah satunya adalah media pembelajaran berbasis multimedia, yaitu media pembelajaran yang menggabungkan dua atau lebih unsur media visual, audio, dan video. Multimedia pembelajaran interaktif digunakan untuk menyampaikan informasi pembelajaran melalui perpaduan teks, gambar, animasi, video, dan suara. Multimedia merupakan bagian dari teknologi yang dapat mempermudah siswa ikut serta dalam proses belajar. Multimedia merupakan salah satu media sebagai solusi untuk memecahkan masalah belajar siswa (Khusniyah \& Muhtadi, 2018). Manfaat multimedia tercermin dalam kemudahan penggunaan dan penggunaan aplikasi multimedia untuk pembelajaran di kelas. Teknologi dan aplikasi multimedia akan membantu siswa berinteraksi melalui media (Elmagzoub dan Babiker, 2015). Multimedia pembelajaran akan menyertakan siswa dalam sebuah pengalaman multisensory yang akan memudahkan pembelajaran. Menurut Mayer (2009), Materi yang disampaikan guru akan lebih dipahami apabila disajikan dengan katakata dan gambar dibandingkan kata-kata atau gambar saja.

Multimedia yang efektif memerlukan perpaduan dengan mengambil manfaat dari setiap karakteristik single media untuk diaplikasikan pada materi pembelajaran. Materi pembelajaran yang disiapkan dengan 
tingkat interaktivitas yang tinggi, dapat memberikan daya tarik yang lebih kuat. Multimedia pembelajaran juga mampu menciptakan lingkungan pembelajaran kapan saja dan di mana saja (Nazir dkk., 2012, p. 821).

Multimedia pembelajaran memfasilitasi penguasaan keterampilan dasar dari siswa yaitu berupa drill dan praktik. Multimedia menjadi salah satu solusi dalam mengatasi masalah melalui learning by doing, memperjelas konsep abstrak, memfasilitasi pembelajaran individu secara kooperatif, membantu dalam pengelolaan aktivitas kelas dan memberikan kemudahan pada aspek pembelajaran yang tidak dapat secara langsung dilakukan. Multimedia juga efektif dalam meningkatkan kemampuan dan retensi (daya ingat) siswa dalam pembelajaran (Shi, 2017).

Adanya pandemic Covid-19, mengharuskan sistem pembelajaran di Indonesia dilaksanakan melalui daring (dalam jaringan). Artinya, system pembelajaran pada masa pandemic covid-19 tidak dilaksanakan secara tatap muka di sekolah akan tetapi melalui online menggunakan jaringan internet. Banyak kendala yang dialami pada pelaksanakan sistem pembelajaran daring ini.

Namun, pada kenyataannya hal tersebut menjadi tantangan baru untuk pada pendidik dan peserta didik serta pemangku kepentingan yang terlibat di dalamnya.

Sistem pembelajaran sebelum pandemi, yaitu tatap muka di kelas memberikan kemudahan tersendiri bagi guru dan siswa. Namun, dalam kondisi ini guru dan siswa 'dipaksa' melaksanakan pembelajaran menggunakan perangkat komputer atau laptop dan perangkat gawai yang lain seperti smartphone yang dapat terhubung dengan jaringan internet. Agar proses pembelajaran dapat dilaksanakan dengan baik, salah satu solusinya adalag guru diharapkan dapat merancang media pembelajaran yang tepat untuk siswa dengan memanfaatkan media daring.

Maka dari itu, kegiatan workshop ini bertujuan untuk melatih para dan calon pendidik untuk merancang multimedia pembelajaran menggunakan Microsoft Power Point mengingat begitu pentingnya media pembelajaran yang dapat menarik minat belajar siswa. Adanya praktik membuat multimedia pembelajaran secara langsung diharapkan dapat membuat calon guru menjadi lebih mahir dalam merancang pembelajaran yang kreatif dan inovatif sesuai bidang mengajar guna menunjang efektivitas dan efisiensi pembelajaran di kelas sehingga keberhasilan tujuan pembelajaran dapat dicapai. Indrawati, (2009) menyebutkan bahwa keikutsertaan dalam kegiatan worksop, kursus, dan pelatihan, bertujuan untuk meningkatkan mutu guru secara signifikan. Apabila mutu guru meningkat maka kualitas pembelajaran juga akan meningkat.

\section{BAHAN DAN METODE}

Kegiatan Workshop Pembuatan Multimedia Pembelajaran Menggunakan Microsoft Power Point untuk Guru Sekolah Dasar ini dilaksanakan pada 21-22 Agustus 
2021 secara daring menggunakan aplikasi

Google Meeting mengingat kondisi masih dalam masa pandemi Covid-19. Sasaran kegiatan workshop ini adalah mahasiswa, guru, dan masyarakat umum, khusunya di Kabupaten Ngawi dan umumnya di seluruh Indonesia.

Metode yang digunakan pada kegiatan ini adalah metode pendekatan teoritis dan empiris (campuran) yang terdiri dari pemaparan materi, diskusi, dan praktik. Praktik dilaksanakan dalam beberapa tahapan, yaitu persiapan desain multimedia, persiapan bahan materi, dan pembuatan komponen multimedia pembelajaran yang terdiri dari halaman judul, halaman menu utama, halaman kompetensi inti dan kompetensi dasar (KI/KD), halaman materi, halaman Latihan, halaman evaluasi, halaman bantuan dan halaman profil. Peserta mempraktikkan pembuatan multimedia pembelajaran secara langsung menggunakan komputer atau laptop yang dipandu oleh narasumber melalui aplikasi Google Meeting.

$$
\text { Berikut langkah-langkah yang }
$$

dilakukan oleh peserta pada tahapan praktik:

(1) Tahap pertama menyiapkan desain multimedia. Pada tahap ini, peserta menyiapkan desain multimedia yang akan dibuat sekaligus menyiapkan bahan untuk mendesain multimedia seperti gambar, suara/music, animasi, dan lain-lain. Desain multimedia meliputi layout dan tampilan setiap halaman, penentuan letak gambar, suara/music, animasi pada setiap halaman, dan kesesuaian desain dengan karakteristik siswa.

(2) Tahap kedua menentukan bahan materi.
Pada tahapan ini, peserta mempersiapkan materi yang akan disajikan dalam multimedia pembelajaran. Materi harus memiliki sumber yang valid seperti buku teks dan artikel jurnal. Kelengkapan materi terdiri dari Tujuan pembelajaran, $\mathrm{KI} / \mathrm{KD}$, materi, dan soal-soal.

(3) Tahap ketiga membuat komponen multimedia pembelajaran. Pada tahap ini, peserta mengaplikasikan desain multimedia yang telah dirancang pada tahap pertama, pada setiap komponen yaitu halaman judul, halaman menu utama, halaman kompetensi inti dan kompetensi dasar (KI/KD), halaman materi, halaman Latihan, halaman evaluasi, halaman bantuan dan halaman profil menggunakan Microsoft Power Point.

\section{HASIL}

Kegiatan Pengabdian kepada Masyarakat dalam bentuk Workshop Pembuatan Multimedia Pembelajaran Menggunakan Microsoft Power Point untuk Guru Sekolah Dasar ini dilaksanakan selama dua hari, berlangsung pada Sabtu-Minggu, 2021 Agustus 2021 secara daring melalui Google Meet. Pada hari pertama kegiatan workshop, Sabtu, 20 Agustus 2021 narasumber menyampaikan materi berjudul "Penerapan Desain Pesan Pada Multimedia Pembelajaran" diselingi dengan diskusi. Hari berikutnya, Minggu, 21 Agustus 2021 narasumber kembali menyampaikan materi berjudul "Pembuatan Multimedia Pembelajaran Menggunakan Microsoft Power Point sekaligus 
mempraktikkan bagaimana membuat

multimedia pembelajaran menggunakan

Microsoft Power Point yang diikuti oleh peserta workshop dengan mempraktikkan secara langsung pembuatan multimedia menggunakan komputer atau laptop.

Peserta yang terdaftar mengikuti kegiatan workshop ini sebanyak 30 orang dari kalangan guru dan siswa. Kegiatan workshop dilaksanakan secara daring menggunakan perangkat komputer atau laptop yang mungkin diakses dimanapun asalkan terhubung dengan koneksi jaringan internet. Jumlah peserta yang berpartisipasi dari awal hingga akhir kegiatan dinilai konsisten.

Narasumber sekaligus instruktur kegiatan workshop ini ialah dosen dari program studi PGSD STKIP Modern Ngawi, Tri Wardati Khusniyah, S. Kom., M. Pd.

Kegiatan workshop berlangsung dengan sangat baik. Para peserta sangat antusias dalam mengikuti seluruh kegiatan. Pada akhir kegiatan workshop, beberapa peserta yang diberikan kesempatan untuk mendemokan produk multimedia pembelajaran yang telah dibuat. Demonstrasi produk ini sekaligus mengevaluasi pemahaman, kemampuan, dan daya kreativitas peserta tersebut dalam membuat multimedia pembelajaran. Narasumber juga meminta peserta untuk mengirimkan hasil/karya produk melalui email panitia.

\section{PEMBAHASAN}

Pembelajaran yang dilakukan secara tatap muka non daring (offline) biasanya lebih sering menggunakan metode ceramah dalam penyampaian materinya. Bahkan, tidak didukung dengan penggunaan media pembelajaran yang efektif, Salah satu permasalahan yang dihadapi pada pembelajaran tatap muka non daring adalah pada saat praktikum. Alat dan bahan praktikum yang kurang memadai menunjukkan bahwa sistem pembelajaran non- aring juga tidak lepas dari kekurangan.

Pandemi Covid-19 ini menambah permasalahan dalam dunia Pendidikan. Akibatnya, pemerintah memberikan kebijakan untuk mengalihkan dari sistem pembelajaran non-daring ke sistem daring. Sampai saat ini, pandemic Covid-19 telah menjangkiti negara Indonesia kurang lebih satu setengah tahun. Selama satu setengah tahun ini sistem pembelajaran daring telah dilaksanakan dan terus dievaluasi. Guru yang dulu massih awam dengan teknologi, pada massa pandemic ini berlomba dan belajar untuk berinovasi dalam menyediakan media pembelajaran yang efektif untuk siswa. Kondisi inilah yang melatarbelakangi terselenggaranya kegiatan workshop pembuatan multimedia pembelajaran menggunakan Microsoft Power Point secara daring ini, sebab diperkirakan tidak sedikit guru yang ingin meningkatkan kreativitas dan inovasi yang bermanfaat untuk pembelajaran. Selain itu multimedia pembelajaran dapat menarik perhatian siswa dan merangsang kemampuan berpikir siswa. Multimedia pembelajaran menciptakan pembelajaran yang lebih menarik dan menyenangkan, membuat pelajaran yang rumit 
menjadi lebih jelas dan mudah dipahami, konsep abstrak menjadi konkret, dan dapat dilakukan dimanapun dan kapanpun, serta efisien ruang dan waktu.

Pada hari pertama narasumber menyampaikan materi pengantar sebagai bahan referensi bagi peserta untuk melakukan praktik membuat multimedia pembelajaran menggunakan Microsoft Power Point di hari berikutnya. Peserta menyimak pemaparan materi dan diskusi dengan antusias. Secara umum, kegiatan workshop ini berjalan dengan lancar.

Kegiatan Pengabdian kepada Masyarakat ini bukan merupakan suatu kegiatan yang baru, dengan kata lain sudah ada yang melakukan kegiatan serupa sebelumnya, namun demikian manfaat mengikuti kegiatan ini dapat diaplikasikan secara langsung oleh peserta. Diantaranya, pernah diterbitkan artikel dengan judul "Pengembangan multimedia pembelajaran berbahasa Arab" oleh Tri Wardati Khusniyah yang berkaitan dengan pengembangan multimedia pembelajaran menggunakan Microsoft Power Point.

\section{KESIMPULAN DAN SARAN}

Kegiatan Workshop Pembuatan

Multimedia Pembelajaran menggunakan

Microsoft Power Point berlangsung dengan sangat baik. Peserta menunjukkan antusiaisme dalam mengikuti kegiatan workshop dari awal hingga acara berakhir. Melalui kegiatan workshop ini, peserta dilatih mengoperasikan komputer atau laptop dalam membuat multimedia pembelajaran menggunakan Microsoft Power Point.

Saran yang direkomendasikan yaitu pelaksanaan kegiatan serupa secara intensif dan berkelanjutan dan Dinas Pendidikan dan Kebudayaan (Disdikbud) Kabupaten Ngawi dengan bekerjasama dengan pihak-pihak terkait, memfasilitasi, dan mengelaborasikan kegiatan-kegiatan sejenis untuk meningkatkan kualitas dan profesionalisme guru.

\section{UCAPAN TERIMA KASIH}

Panitia mengucapkan terima kasih yang sebesar-besarnya kepada:

(1) LPPM STKIP Modern Ngawi, dan

(2) Ketua Program Studi PGSD STKIP Modern Ngawi

yang telah memonitor terlaksananya kegiatan pengabdian kepada masyarakat dalam bentuk workshop ini sehingga dapat terlaksana dengan sangat baik.

\section{DAFTAR PUSTAKA}

Elmagzoub, M., \& Babiker, A. (2015). For effective use of multimedia in education, teachers must develop their own educational multimedia applications assit. TOJET: The Turkish Online Journal of Educational Technology, 14(4), 62-68

Indrawati. 2009. "Pengelolaan Pelatihan PCT, DCT, dan Guru Pemandu di KKG/MGMP Program Bermutu: Panduan." Jakarta: Depdiknas, Dirjen PMPTK.

Khusniyah, T. W., \& Muhtadi, A. (2018). DEVELOPING ARABIC LANGUAGE LEARNING MULTIMEDIA. Jurnal Kependidikan: Penelitian Inovasi Pembelajaran, 2(2), 247-261. https://doi.org/10.21831/jk.v2i2.18856 
Kirom, Askhabul. 2017. "Peran Guru dan Peserta Didik dalam Proses Pembelajaran Berbasis Multikultural." Jurnal Pendidikan Agama Islam, Volume 3 (1): 69 - 80.

Mayer, R. E. (2009). Multimedia learning: Prinsip-prisip dan aplikasi. Yogyakarta: Pustaka Pelajar

Musfiqqon. 2012. "Pengembangan Media dan Sumber Pembelajaran." Jakarta: Prestasi Pustaka.

Nazir, M. I. J., Rizvi, A. H., \& Pujeri, R. V. (2012). Skill development in multimedia based learning environment in higher education: An operational model. International Journal of Information and Communication Technology, 2(11), 820-828

Putra, M. I., Ariawan, K. U., dan Sutaya, I. W. 2017. "Pengembangan Media Pembelajaran Berbasis Camtasia Studio Video CD Interaktif Multimedia untuk Mata Pelajaran Pemrograman Web di Jurusan Multimedia SMK Negeri 3
Singaraja." Jurnal Pendidikan Teknik Elektro Undiksha, Volume 6 (1): 1 - 8.

Shi, X. (2017). Application of multimedia technology in vocabulary learning for engineering students. Ijet, 12(1), 21-31.

Sudrajat, Akhmad. 2008. "Pengertian Pendekatan, Strategi, Metode, Teknik dan Model Pembelajaran." Bandung: Sinar Baru Algensindo.

Tri Wardati Khusniyah, Santy Dinar Permata, \& Uci Ulfa Nurafifah. (2021). WORKSHOP PEMBUATAN VIDEO PEMBELAJARAN

MENGGUNAKAN APLIKASI

CAMTASIA STUDIO DENGAN TEMA PEMBELAJARAN 'ASIK' DI MASA PANDEMI. IJCE (Indonesian Journal of Community Engagement), 2(1), 1-7. https://doi.org/10.37471/ijce.v2i1.213

\section{LAMPIRAN}

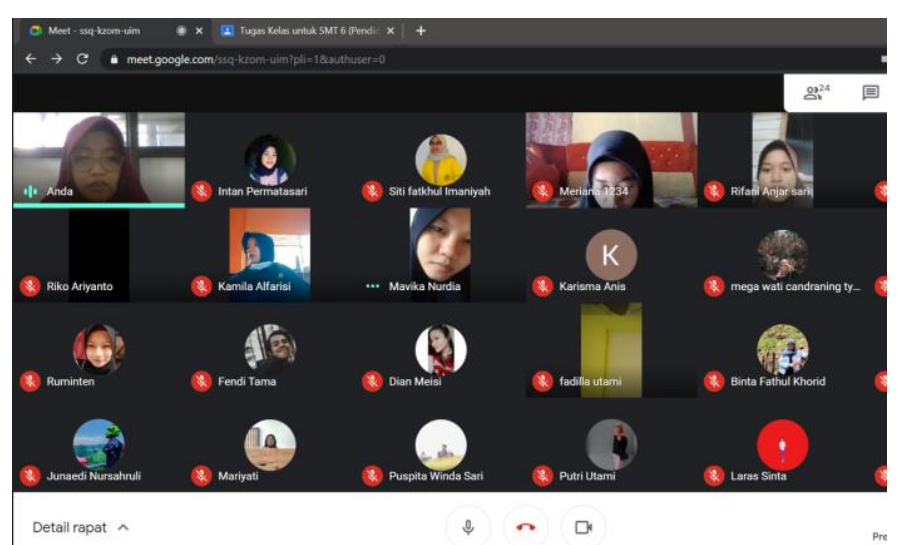

Gambar 1. Pemaparan Materi melalui Aplikasi Google Meet

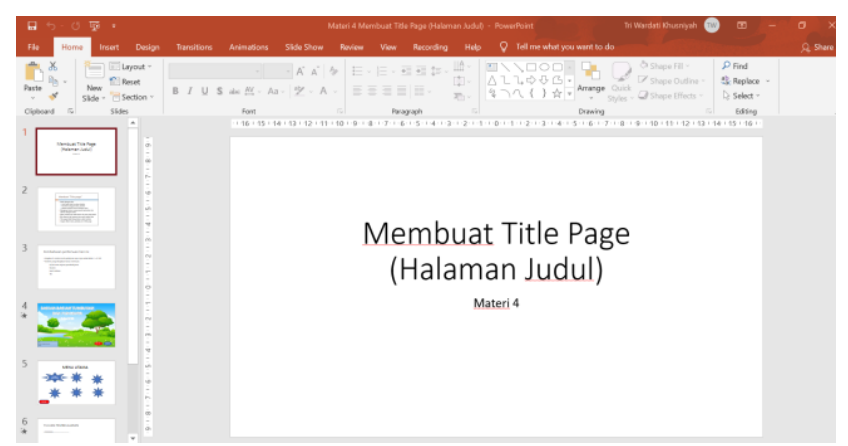

Gambar 2. Tampilan Layar Power Point 